\title{
Landscape Structural Indicators as a Tool to Assess Land Use Changes in Planning for Sub-Basin Sustainability (Southeastern Brazil)
}

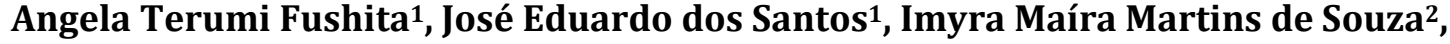 \\ Eduarda Romanini2 ${ }^{2}$ Rômulo Theodoro Costa ${ }^{2}$ \\ ${ }^{1}$ Analysis and Environmental Planning Laboratory, Department of Hydrobiology, Federal University of São \\ Carlos (UFSCar), São Carlos, Brazil \\ ${ }^{2}$ Pos-Graduate Programme in Ecology and Natural Resources, Federal Universityof São Carlos (UFSCar), São \\ Carlos, Brazil \\ Email: angela_fushita@yahoo.com.br
}

Received 3 February 2016; accepted 26 April 2016; published 29 April 2016

Copyright (C) 2016 by authors and Scientific Research Publishing Inc.

This work is licensed under the Creative Commons Attribution International License (CC BY). http://creativecommons.org/licenses/by/4.0/

(c) (i) Open Access

\begin{abstract}
Land use is shaped by the interactions between nature and society, and these interactions can inhibit environmental sustainability and deplete the natural capital that provides the ecosystem services upon which humans depend. Urbanity Index and Landscape Vulnerability Indicator have been proposed to improve the impact interpretability of land use changes on sub-basin sustainability for local scenarios of biodiversity conservation. A time series of LandSat 5 Thematic Mapper remote sensing data from São Carlos municipality, Southeastern Brazil, for the years 1989, 2004 and 2014 revealed that land use changes in the sub-basins do not take place in a progressive and gradual way. Over the 25-year period, the main trends showed the loss and increase of forest cover so that it has remained quantitatively similar over time due to reduced agricultural land use. The aggregation of both indicators enabled the identification of greater naturalness and lower vulnerability, as well as lower naturalness and higher vulnerability under local sub-basin conditions, pointing the need for different strategies for sub-basin biodiversity conservation and sustainability. These preliminary scenarios provide a way to communicate problems of environmental sustainability at different landscape scales to the scientific community as well as to planners, policy makers and the broader public.
\end{abstract}

\section{Keywords}

Land Use, Quantifiable Indicator, Urbanity Index, Landscape Vulnerability Indicator

How to cite this paper: Fushita, A.T., dos Santos, J.E., de Souza, I.M.M., Romanini, E. and Costa, R.T. (2016) Landscape Structural Indicators as a Tool to Assess Land Use Changes in Planning for Sub-Basin Sustainability (Southeastern Brazil). Journal of Water Resource and Protection, 8, 482-492. http://dx.doi.org/10.4236/jwarp.2016.84041 


\section{Introduction}

The global changes in land use over the last fifty years have resulted in improvements to human welfare and economic development, but they have also caused serious environmental problems [1] [2].

The analysis of temporal and spatial changes in land use and cover is essential to landscape planning focused on the conservation of life support systems [3]-[5].

Changes in the landscape due to land use practices [6] result from interactions between abiotic and socioeconomic factors [7] [8], such as rural culture and different types of agricultural technology [9]-[11].

Anthropization in response to socio-economic factors defines the land use and cover and natural resource patterns [4] [7] [12] [13] that, in turn, define the spatial patterns of the cultural landscape, which incorporates diverse aesthetic, economic and ecological values and can drive habitat degradation and soil loss and impoverish life support systems [5]. These processes interfere with sustainability as they deplete the natural capital that provides goods and services through different land uses, and they represent the most relevant economic, environmental and societal issues to a region. They further enable the identification of land use functions that are hindered or enhanced under various land use change scenarios [2] [14].

The assessment of ecosystem sustainability requires a set of indicators that can be used at different spatial, temporal and hierarchical levels. Structural landscape indicators are ecologically sensitive tools that reflect the correlation between multiple land uses, their temporal and spatial changes, and the influence that policies might have on steering those changes towards sustainability [2] [5] [15]-[17]. These tools also allow the dynamics of the naturalness of a landscape, which can decrease or increase due to anthropic activities, to be monitored in time and space. This can provide essential information about current and historical conditions and the interactions between nature and society, which can be disseminated to the scientific community, the general public and decision makers.

This study examines the interactions between different land uses, their temporal and spatial changes between 1989 and 2014, and how these changes have affected environmental sustainability in the São Carlos municipality with the goal of answering the following questions:

1) Do structural landscape indicators distinguish changes in naturalness and vulnerability as a result of land use change?

2) Did the environmental sustainability of the sub-basins of the São Carlos municipality change over the 25-year period?

\section{Methods}

\subsection{Characterization of the Study Area}

The São Carlos municipality covers an area of $1136.907 \mathrm{~km}^{2}$ and is located in the northeast region of São Paulo state, Southeastern Brazil, between $47^{\circ} 30^{\prime}$ and $48^{\circ} 30^{\prime} \mathrm{W}$ and $21^{\circ} 30^{\prime}$ and $22^{\circ} 30^{\prime} \mathrm{S}$. Ten sub-basins have been delimited within the municipality (Figure 1).

According to a demographic census, São Carlos municipality had a total population of 221,950 inhabitants in 2014 [18]. Its primary vegetation cover is characterized by various savanna physiognomies.

Initial reports of landscape change in the São Carlos municipality due to human influence date back to the end of the seventeenth century and the beginning of local settlement. The vegetation at this time was reported to be savanna, sparsely arboreal savanna, and marsh (27\%); arboreal savanna (16\%); semi-deciduous forest and riparian forest (55\%), and deciduous forest with Araucaria angustifolia (Bert.) O. Ktze (2\%). Three centuries later, in 1994, the natural vegetation was evaluated via aerial photographs and found to cover $7 \%$ of the total area of the municipality. The vegetation was composed of savanna (2\%), arboreal savanna (2.5\%), semi-deciduous and riparian forests (1\%), and areas of regeneration (1.5\%); the A. angustifolia semi-deciduous forest was extinct [19].

From 1991 to 2000, surveys of legal proceedings involving deforestation in São Carlos municipality identified the loss of 1121.62 ha of natural vegetation, approximately 100 ha/year, which was threatening water quality and causing habitat degradation and the loss of biodiversity. The total area of natural and semi-natural vegetation was estimated to be $14.1 \%$ of the total area if the municipality [20].

Based on screen digitization of Landsat-5 Thematic Mapper (TM) imagery, natural vegetation covered 28\% (31,776.4 ha) of the São Carlos municipality in 2012 [21]. 


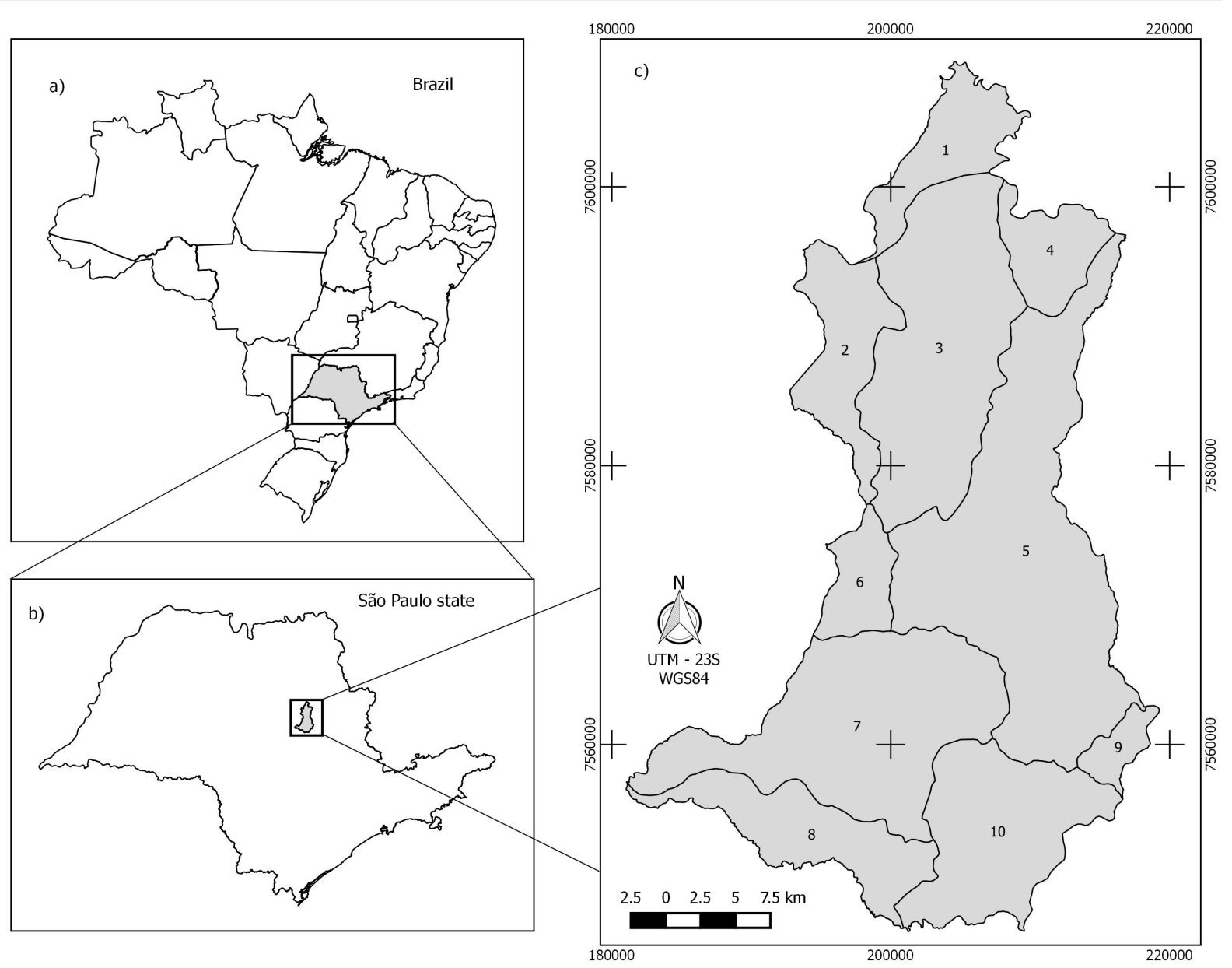

Figure 1. (a) Location of São Paulo state (Brazil); (b) location of São Carlos municipality, São Paulo state (Southeastern Brazil); (c) detailed representation of boundaries of São Carlos municipality and the sub-basin boundaries: Ribeirão das Guabirobas (1), Ribeirão das Cabaceiras (2), Ribeirão de Araras (3), Rio Mogi-Guaçu (4), Rio do Quilombo (5), Chibarro (6), Ribeirão do Pântano (7), Monjolinho (8), Jacaré-Guaçu (9), and Feijão (10).

\subsection{Land Use Dynamics}

The template is used to format your paper and style the text. All margins, column widths, line spaces, and text Land use dynamics were characterized by screen digitizing Landsat imagery with a spatial resolution of $30 \mathrm{~m}$ and a multispectral composite of three bands near the infrared, red and green wavelengths. Landsat-5 (TM) imagery (path 220; row 075) was obtained for 24 October 1989 and 30 August 2004, and Landsat-8 Operational Land Imager (OLI) imagery was also used for 7 June 2014.

The land use and cover typologies were discriminated by tone, texture and context criteria [22] [23] through manual polygon digitalization (visual interpretation) in MapInfo 10 software. Each polygon was related to a previously established land use and cover: pasture, annual and perennial cultivation, exposed soil, forestry, forest, savanna, short-shrub savanna, aquatic, wetland, and settlement. The land use types were classified based on decreasing naturalness or increasing artificiality [24].

\subsection{Structural Landscape Indicators}

The environmental impacts that land use changes have had on naturalness and landscape vulnerability were analyzed based on the Urbanity Index (UI) and the Landscape Vulnerability Index (LVI). For this procedure, land use was considered to be the main driver of change in the ecosystem [1]; this study did not consider indirect drivers related to demographic, economic, socio-political, cultural, religious, scientific or technological conditions [14] [25]. 
The UI [26] reflects the naturalness of the landscape condition and estimates (Equation (1)) the extent to which landscapes are dominated by strongly human-altered systems [17]:

$$
\mathrm{UI}=\log _{10}\left[\frac{\mathrm{A}+\mathrm{U}}{\mathrm{F}+\mathrm{W}}\right]
$$

where U correspond to urban area; Agricultural area; F forest area, and W aquatic and wetland areas. The spatial representation of the UI was obtained based on the RASTER VECTOR, AREA and IMAGE CALCULATOR commands in the IDRISI Selva software [27] and fuzzy logic (transformed by a linear function with a minimum value of 0 and a maximum value of 1 ). This representation considers the maximum degree of naturalness (UI = 0 ) and the minimum degree of naturalness (UI $=1$ ), which correspond to the predominance of strongly human-altered systems. This index doesn't measure unit.

The LVI indicates the susceptibility of a landscape to environmental impacts, i.e., environmental vulnerability decreases as the ability of the landscape to minimize environmental impacts increases [16] [28] [29]. The LVI values were obtained by two metrics, the Vegetation Quality Index (VQI) and the Water Quality Index (WQI) (Equation (2)).

$$
\mathrm{LVI}=\frac{\mathrm{VQI}+\mathrm{WQI}}{2}
$$

The VQI was adapted from the Environmental Quality Index [30], and the WQI is based on the functional curves from the Habitat Quality Index [29]. This approach assumes that land use and cover are related to the environmental vulnerability of the vegetation and water.

The VQI was estimated (Equation (3)) from the values of three metrics of vegetation patches: Area (AREA), shape (SHAPE) and distance (DISTANCE) between patches, which were obtained from the land use reclassification of the São Carlos municipality for 1989, 2004 and 2014. IDRISI Selva software was used to adjust the VQI, WQI and LVI values by fuzzy logic with a minimum value of 0 and a maximum value of 1 .

$$
\mathrm{VQI}=\frac{\text { AREA }+ \text { SHAPE }+ \text { DISTANCE }}{3}
$$

The WQI describes the susceptibility of water, which is related to the distances between water resources and the sources of impact represented by different land uses. The distances were estimated by the DISTANCE module in IDRISI Selva [27] and transformed by fuzzy logic with a minimum value of 0 and a maximum value of 1 .

After transformation by fuzzy logic, with a minimum value of 0 and a maximum value of 1 , the LVI values were represented spatially; a higher LVI value (1) reflected lower landscape resilience, and a lower LVI value (zero) reflected higher landscape resilience. This index doesn't measure unit.

A permutational multivariate analysis of variance (PERMANOVA) [31] [32] with Euclidian distance was used to test the null hypothesis of equal degrees of naturalness and landscape vulnerability, based on UI and LVI values, between 1989, 2004 and 2014. A pair-wise a posteriori comparison was performed on a subsample of 500 points, which were randomly sampled from each time period $(1989,2004,2014)$ without overlap for a total of 1500 sampling points.

\subsection{Forecasted Environmental Sustainability Scenarios}

The recognition that land use changes affect multiple dimensions of sustainability has been embodied by the concept of ecosystem goods and services [33] or environmental functions [34]. This concept is particularly useful for identifying the environmental, social and economic functions of land use [35] [36] as part of sustainable land development; it even requires an assessment of the impact of land use change on the three dimensions of sustainability [2].

The São Carlos sustainability assessment was based on the natural/cultivated land use and mainly focused on environmental sustainability at the sub-basin level.

The environmental sustainability outcomes due to land use changes in different sub-basin-level scenarios were interpretable through overlapping UI and LVI values for 1989, 2004 and 2014 using the OVERLAY command in IDRISI Selva.

To test the null hypothesis of equal degrees of environmental sustainability between sub-basins in 1989, 2004 and 2014, the PERMANOVA test was applied [31] [32] with Euclidian distance. A pair-wise a posteriori com- 
parison of 100 randomly sampled points with no overlap for a total of 3000 sampling points was used.

The sampling was accomplished with the "dismo" [37] and "raster" [38] packages for program R [39], and the PERMANOVA test was performed with the "vegan” package.

\section{Results and Discussion}

\subsection{Land Use}

Four primary land uses were identified for 1989, 2004 and 2012: 1) forest, including secondary forest, savanna and short-shrub savanna without direct human influence; 2) anthropogenic agricultural, which is created by human influence and includes pasture, perennial and annual crops, bare soil and forestry; 3) anthropogenic nonagricultural, which includes settlements, road networks, industrial complexes, and mining areas, and 4) water (Figure 2).

The changes in land use in São Carlos municipality depend on history, social and economic conditions, and ecological context, and do not progress in a linear way. Over the 25-year period, the main trends in the landscape include the loss and increase of forest cover so that it has remained quantitatively similar over time due to reduced anthropogenic agricultural land use and increased anthropogenic non-agricultural land cover, respectively. The minimal changes in forest cover, from 26.91 to 26.38\% from 1989 to 2014 (Figure 2), highlights forest recovery to a similar quantitative condition as evaluated 25 years ago.

The anthropogenic agricultural land use type declined from $66.60 \%$ to $63.08 \%$ of the total area of the São Carlos municipality over the 25-year period (1989 to 2014) (Figure 2). This decreasing artificiality might be related to local or regional agriculture mechanization, which has made planting and harvesting on steeper slopes impossible and thereby promoted the recovery of natural areas. Agricultural activity related to sugar cane cultivation was the main driver of habitat change between 1989 and 2014.

The increasing anthropization of the São Carlos municipality (71.02\% to 72.26\%, between 1989 and 2014) has been promoted by an increase in anthropogenic non-agricultural land use (4.42\% to $9.18 \%$ between 1989 and 2014) (Figure 2). While urbanization was not a predominant driver of change compared to anthropogenic agricultural land use, the demographic data for the São Carlos municipality [18] indicate increased urbanization with a population growth of 66\%, from 158,221 to 238,958 inhabitants, between 1991 and 2014.
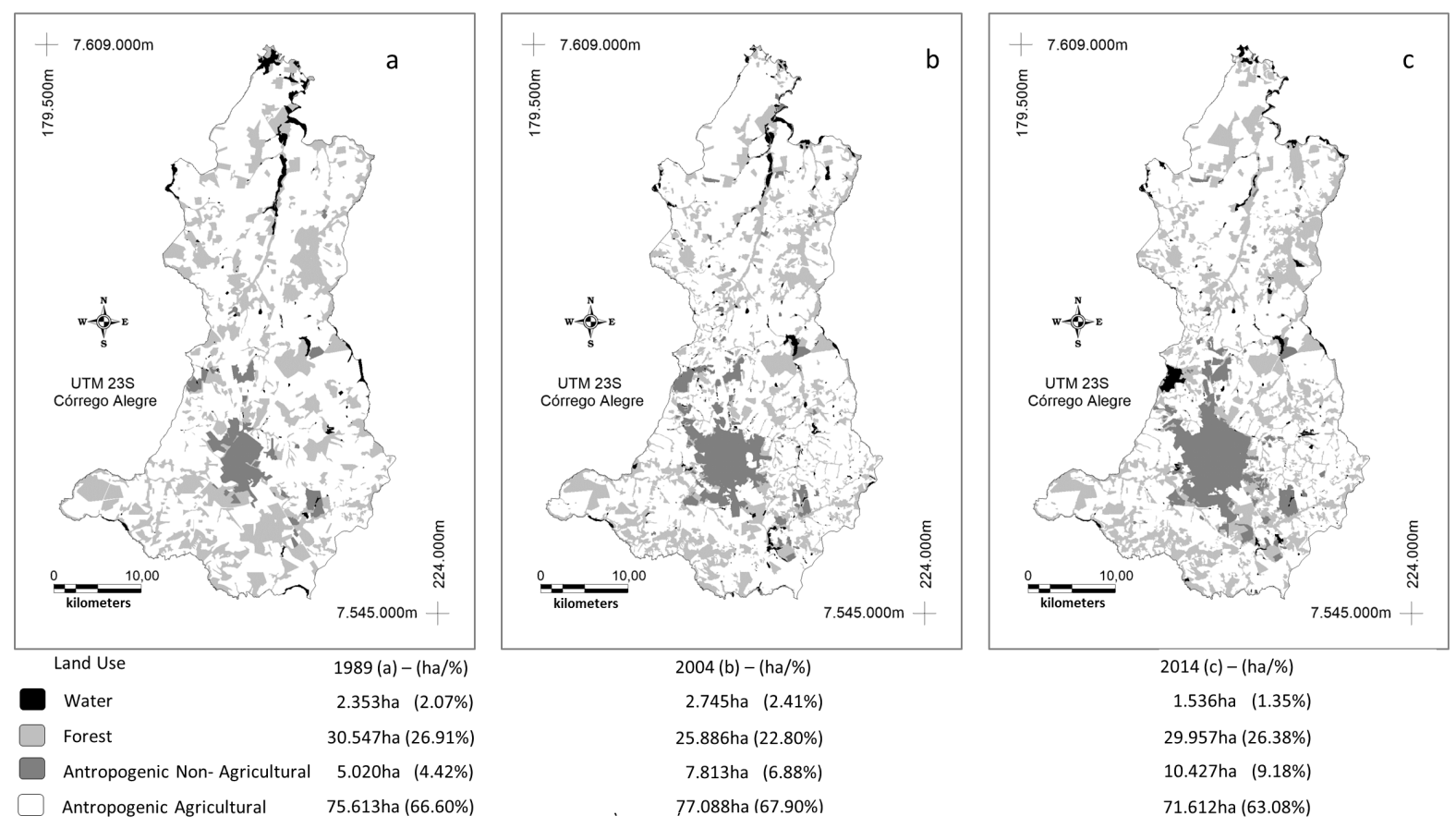

Figure 2. Land use dynamics (ha and \%) in the São Carlos municipality (São Paulo, Southeastern Brazil) in 1989 (a), 2004 (b), and 2014 (c). 
Water cover decreased from $2.07 \%$ to $1.35 \%$ of the total area of the São Carlos municipality between 1899 and 2014 (Figure 2), which is likely due to a period of prolonged drought that began in 2013. This drought, which caused a collapse in the water supply, is considered an extreme weather event, and records of increased average temperature and reduced rainfall at national and local scales suggest that water crises similar to that from 2013 to 2015 could become routine. However, the land use changes in the São Carlos municipality, i.e., deforestation, changes in the extent of cultivated lands, and urbanization, are processes that are not strongly affected by interannual climatic variability.

\subsection{Landscape Sustainability Index}

The UI and LVI values for 1989, 2004 and 2014 that resulted from the various land use change scenarios for the São Carlos municipality are shown in Figure 3(a), Figure 3(b), and Figure 3(c) and Figure 3(d), Figure 3(e), and Figure 3(f), respectively. Areas with high naturalness and low vulnerability (UI and LVI values $<0.3$ ) were characterized by conditions favorable to environmental sustainability, whereas those with low naturalness and
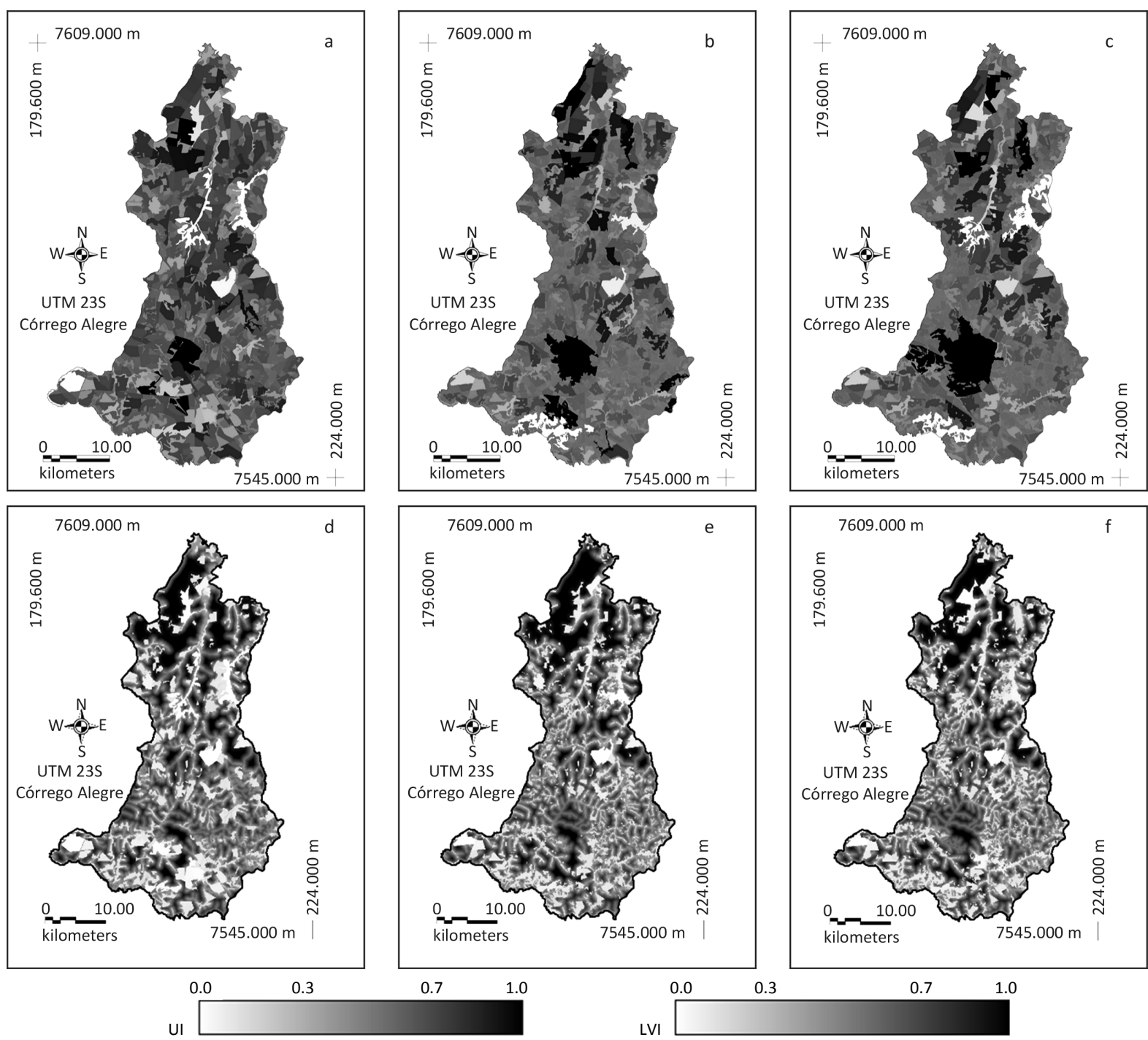

Figure 3. Spatial representation of Urbanity Index (UI) and the Landscape Vulnerability Index (LVI) values resulting from land use changes scenarios for São Carlos municipality (SP, Southeastern Brazil)). The legend represents the urbanity (1989a, 2004b and 2014c) and landscape vulnerability (1989d, 2004e e 2014f) range values, maximum (1) and minimum (0), related to the extent to which the landscape was occupied by anthropic systems and the capacity for mitigating impacts, respectively. 
high vulnerability (UI and LVI > 0.7) exhibited conditions unfavorable to environmental sustainability. The results for the pair wise comparison test can be found as a supplementary material for this article.

However, the UI and LVI values for 1989, 2004 and 2014 for São Carlos municipality were not significantly different at the $5 \%$ level $(\mathrm{F}=0.584 ; \mathrm{p}=0.543)$, were interchangeable, and could be assigned at random to the three periods in accordance with the null hypothesis.

The total municipal area required to support agricultural and urban expansion $(71.02 \%$ to $72.26 \%$ between 1989 and 2014) increased by 1.2\% over 25 years (Figure 2) with dominance of anthropogenic agricultural land use. There was minimal change in forest cover, from $26.91 \%$ to $26.38 \%$, over the 25 -year period (1989 to 2014), which has maintained the naturalness and vulnerability of the landscape for 25 years.

In terms of land use dynamics, the spatial patterns of the landscape in the municipality did not change significantly during the 25-year period. Thus, using only time as a factor, it was not possible to demonstrate statistically significant, distinct circumstances of naturalness and landscape vulnerability as drivers of land use change.

The particular sub-basin environmental sustainability scenarios related to naturalness and landscape vulnerability for 1989, 2004 and 2014 are illustrated in Figure 4.

Since the municipal territory corresponds to a mosaic of land uses, and the UI and LVI mean values are not normally distributed, median values were used for each sub-basin as a measure of performance to identify regions with favorable and unfavorable conditions for naturalness and landscape vulnerability.

The boxplots (Figure 5) for each sub-basin display an uneven distribution of the median UI and LVI values for 1989, 2004 and 2014 in relation to favorable (UI and LVI < 0.3) and unfavorable (UI and LVI > 0.7) conditions for environmental sustainability.

The PERMANOVA statistical test revealed statistically significant differences in naturalness and landscape vulnerability between sub-basins ( $F=7.863$; $\mathrm{p}=0.001$ ) at the 5\% level of significance for 1989, 2004 and 2014. A pair-wise a posteriori comparison between each sub-basin was performed for each year studied.

In 1989, except for a few pairs, most of the sub-basins were significantly different at the $5 \%$ level of significance $(\mathrm{F}=7.863 ; \mathrm{p}=0.001)$ in relation to favorable (UI and LVI $<0.3)$ and unfavorable (UI and LVI $>0.7)$ conditions for environmental sustainability. Similar results were observed for 2004 and 2014; most of the sub-basins were significantly different at the $5 \%$ level of significance $(\mathrm{F}=27.07 ; \mathrm{p}=0.001$ and $\mathrm{F}=18.408 ; \mathrm{p}=$ 0.001 , respectively), except for a few pairs.
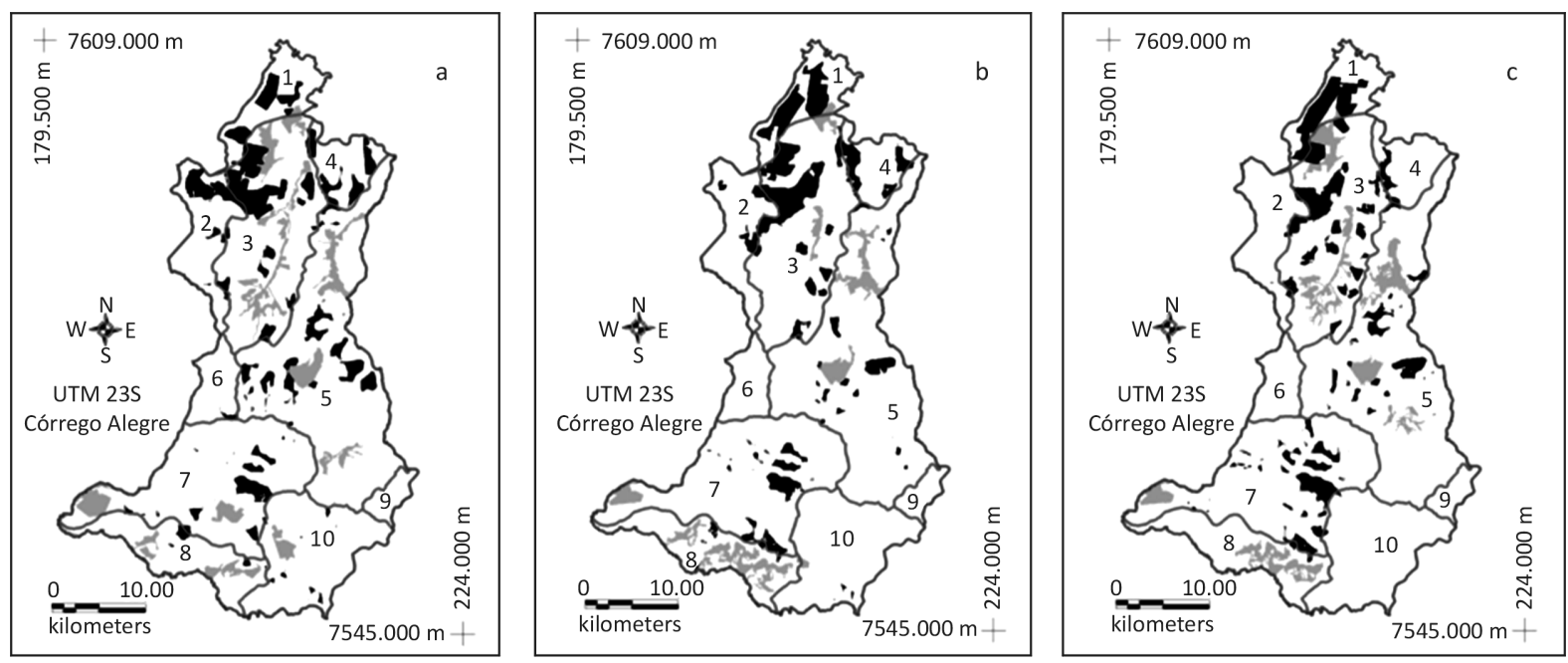

Higher naturalness and lower vulnerability areas (UI and $L V I<0.3$ )
Lower naturalness and higher vulnerability areas (UI and $L V I>0.7$ )
Sub-basin limits: Ribeirão das Guabirobas (1), Ribeirão das Cabaceiras (2), Araras (3), Rio Mogi-Guaçu (4),
Rio do Quilombo (5), Chibarro (6), Monjolinho (7), Jacaré-Guaçu (8), Ribeirão do Pantano (9), Feijao (10)

Figure 4. Environmental sustainability scenarios resulting from Urbanity Index (UI) and Landscape Vulnerability Index (LVI) values for each sub-basin in the São Carlos municipality (SP, Southeastern Brazil) in 1989 (a) 2004 (b) and 2014 (c). Sub-basins: Ribeirão das Guabirobas (1), Ribeirão das Cabaceiras (2), Ribeirão de Araras (3), Rio Mogi-Guaçu (4), Rio do Quilombo (5), Chibarro (6), Ribeirão do Pântano (7), Monjolinho (8), Jacaré-Guaçu (9), Feijão (10). 

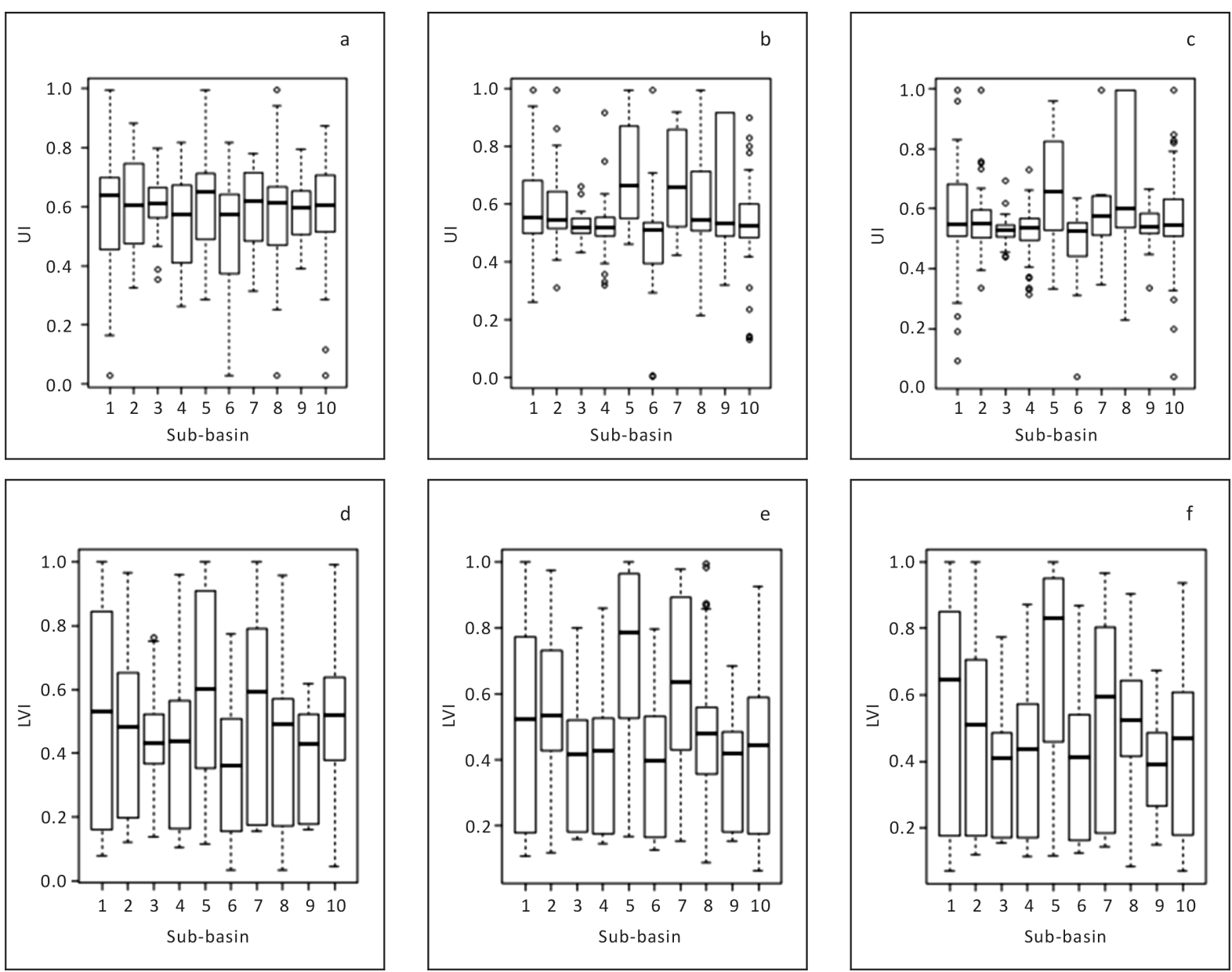

Figure 5. Boxplots with median Urbanity Index (UI) ((a), (b) and (c)) and Landscape Vulnerability Index (LVI) ((d), (e), and (f)) values for 1989 ((a) and (d)), 2004 ((b) and (e)) and 2014 ((c) and (f)). Numbersonthex-axisrepresentthesub-basinsofthe São Carlos municipality (SP, SoutheasternBrazil): (1) Ribeirão de Araras, (2) Cabaceiras, (3) Chibarro, (4) Feijão, (5) Ribeirão das Guabirobas, (6) Jacaré-Guaçú, (7) Mogi-Guaçú, (8) Monjolinho, (9) Quilombo, (10) Ribeirão do Pântano.

Scenarios with higher naturalness and lower vulnerability (UI and LVI $<0.3$ ) featured favorable conditions for environmental sustainability, which were identified in the Jacaré-Guaçú and Feijão sub-basins for 1989, 2004 and 2014 (Figure 4). In the Jacaré-Guaçú sub-basin, this trend is likely due to the reduction in anthropogenic agricultural areas, the prevailing driver of landscape change; a consequent improvement in qualitative integrity (form, area and distance) of the forest fragments; and by virtue of being a basaltic cuestas region located in a legally protected area. The increased naturalness appears to be due to the establishment of new protected areas [20] and by government policies encouraging the recovery of permanent preservation areas.

Lower naturalness and higher vulnerability (UI and LVI > 0.7) scenarios characterized by unfavorable conditions for environmental sustainability were identified in the Monjolinho and Ribeirão das Guabirobas sub-basins for 1989, 2004 and 2014 (Figure 4). This trend is supported by the increase in anthropogenic agricultural and non-agricultural land use and a consequent loss of forest in these two sub-basins. Although urbanization is not the major driver of change in the municipality, the urban area of São Carlos is fully contained within the Monjolinho sub-basin, which has shown increasing urbanization between 1989 and 2014 (Figure 2).

\section{Conclusions}

Expanding the requirements for environmental sustainability, which are defined by median UI and LVI values > 0.7, should adversely affect economic and social development. However, this trend was not evident in the São Carlos municipality over the 25-year study period; the trajectory of land use change exhibits approximately the 
same degree of expansion of natural ecosystems and anthropogenic areas. However, this trajectory of land use change can promote a better understanding of the conditions necessary for environmental sustainability using smaller, more clearly defined spatial resolutions at the sub-basin rather than the municipal scale.

The essential question relates to the uncertainties over the boundaries of each of the different value frameworks (UI values and the percentage of forest land use area since 2014), i.e., the amount of the natural ecosystem that should be conserved for non-utilitarian values considering resilience and option values; its role in providing and sustaining ecosystem services; and, finally, its ability to persist under current trends and policies given the trade-offs with economic development and the growth of anthropogenic agricultural and non-agricultural land uses.

The primary issues are guided by the need to define the size of the municipal area that can be altered for human use in relation to the minimum degree of landscape naturalness that can ensure natural ecosystem maintenance. Additionally, the sub-basin areas should be prioritized to reduce the effects of the drivers of change on local life-support systems so that ecosystem services can be restored.

Fundamental strategies related to the creation and maintenance of legally protected areas and the encouragement of the recovery of life-support areas, whether legally protected or not, to minimize risks to biodiversity are required for landscape biodiversity conservation at the sub-basin or municipality scale.

After running the various land use change scenarios (1989-2004-2014), the three environmental land use functions that were most affected were 1) the provision of abiotic resources, which corresponds to the role of land use change in regulating the supply and quality of water, air and minerals; 2) the support and provision of biotic resources, which correspond to the capacity of the territory to support biodiversity; and 3) the maintenance of ecosystem processes related to agricultural production, hydrological and nutrient cycling, and soil formation. All of these functions are directly related to the level of anthropogenic (agricultural and urban) land use.

This study presents an approach to environmental analysis and planning at a smaller and more clearly defined spatial resolution to promote land use changes that support an environmental sustainability friendly sub-basin scenario. This preliminary scenario can be seen as a provocative, scientifically and experimentally grounded approach that planners and decision makers can discuss to potentially implement spatially explicit policies for their municipality and to expand knowledge about its development and environmental sustainability. The resulting scenario shows the importance of a proactive attitude towards the environment, and it highlights the drivers of change that can be the focus of environmental management agencies in planning, resulting in better policies for activities in pre-established protected areas.

\section{Acknowledgements}

Financial support was provided by the Coordination for the Improvement of Higher Education Personnel (CAPES).

\section{References}

[1] Millennium Ecosystem Assessment-MEA (2003) Ecosystems and Human Well-Being: A Framework for Assessment. Island Press, Washington DC.

[2] Perez-Soba, M., Petit, S., Jones, L., Bertrand, N., Briquel, V., Omodei-Zorini, L., Contini, C., Helming, K., Farrington, J.H., Mossello, M.T., Wascher, D., Kienast, F. and De Groot, R. (2008) Land Use Functions-A Multifuncionality Approach to Assess the Impact of Land Use Changes on Land Use Sustainability. In: Helming, K., Perez-Soba, M. and Tabbush, P., Eds., Sustainability Impact Assessment of Land-Use Changes. Springer Berlin Heidelberg, 375-404. http://dx.doi.org/10.1007/978-3-540-78648-1_19

[3] Christensen, N.L., Bartuska, A.M., Brown, J.H., Carpenter, S., D’Antonio, C., Francis, R., Franklin, J.F., Macmahon, J.A., Noss, R.F., Parsons, D.J., Peterson, C.H., Turner, M.G. and Woodmansee, R.G. (1996) The Report of the Ecological Society of America Committee on the Scientific Basis for Ecosystem Management. Ecol. Appl., 6, 665-691. http://dx.doi.org/10.2307/2269460

[4] Blasi, C., Smiraglia, D. and Carranza, M.L. (2003) Analisimultitemporaledelpaesaggioall'internodiun sistema diclassificazionegerarchicadelterritorio. Il caso deiMontiLepini (ItaliaCentrale). Informatore Botanico Italiano, 35, 3141.

[5] Haberl, H., Wackernagel, M. and Wrbka, T. (2003) Land Use and Sustainability Indicators. An Introduction. Land Use Policy, 21, 193-198. http://dx.doi.org/10.1016/j.landusepol.2003.10.004 
[6] Kienast, F (1993) Analysis of Historic Landscape Patterns with a Geographical Information System: A Methodological Outline. Landscape Ecology, 8, 103-118. http://dx.doi.org/10.1007/BF00141590

[7] Forman, R.T.T. (1995) Land Mosaic. Cambridge University Press, Cambridge.

[8] Zonneveld, I.S. (1995) Land Ecology: An Introduction to Landscape Ecology as a Base for Land Evaluation. Land Management and Conservation. SPB Academic Publishing, Amsterdam.

[9] Bowman, D.M., Walsh, A. and Milne, D.J. (2001) Forest Expansion and Grassland Contraction within a Eucalyptus Savanna Matrix between 1941 and 1992 at Litchfield National Park in the Australian Monsoon Tropics. Global Ecology and Biogeography, 10, 535-548. http://dx.doi.org/10.1046/j.1466-822X.2001.00252.x

[10] Chen, L.D., Wang, J., Fu, B.J. and Qiu, Y. (2001) Land-Use Change in a Small Catchment of Northern Loess Plateau, China. Agriculture, Ecosystems \& Environment, 86, 163-172. http://dx.doi.org/10.1016/S0167-8809(00)00271-1

[11] Hietala-Koivu, R. (2002) Landscape and Modernizing Agriculture: A Case Study of Three Areas in Finland in 19541998. Agriculture, Ecosystems \& Environment, 91, 273-281. http://dx.doi.org/10.1016/S0167-8809(01)00222-5

[12] Irwin, E.G. and Geoghegan, J. (2001) Theory, Data, Methods: Developing Spatially Explicit Economic Models of Land Use Change. Agriculture, Ecosystems \& Environment, 85, 7-23. http://dx.doi.org/10.1016/S0167-8809(01)00200-6

[13] Acosta, A., Carranza, M.L. and Giancola, M. (2005) Landscape Change and Ecosystem Classification in a Municipal District of a Small City (Isernia, Central Italy). Environmental Monitoring and Assessment, 108, 323-335. http://dx.doi.org/10.1007/s10661-005-4332-3

[14] Pereira, H.M., Leadley, P.W., Proença, V., Alkemade, R., Scharlemann, J.P.W., Fernandez-Manjarrés, J.F., Araújo, M.B., Balvanera, P., Biggs, R., Cheung, W.W., Chini, L., Cooper, H.D., Gilman, E.L., Guénette, S., Hurtt, G.C., Huntington, H.P., Mace, G.M., Oberdorff, T., Revenga, C., Rodrigues, P., Scholes, R.J., Sumaila, U.R. and Walpole, M. (2010) Scenarios for Global Biodiversity in the 21st Century. Science, 330, 1496-1501. http://dx.doi.org/10.1126/science.1196624

[15] Wiens, J.A., Stenseth, N.C., Horne, B. and Van, R.A. (1993) Ecological Mechanisms and Landscape Ecology. Oikos, 66, 369-380. http://dx.doi.org/10.2307/3544931

[16] Turner II, B.L., Kasperson, R.E., Matsone, P.A., McCarthy, J.J., Corell, R.W., Christensene, L., Eckley, N., Kasperson, J.X., Luerse, A., Martellog, M.L., Polskya, C., Pulsipher, A. and Schiller, A. (2003) A Framework for Vulnerability Analysis in Sustainability Science. Proceedings of the National Academy of Sciences of the United States of America, 100, 8074-8079. http://dx.doi.org/10.1073/pnas.1231335100

[17] Wrbka, T., Erb, K.H., Schulz, N.B., Peterseil, J., Hahn, C. and Haberl, H. (2004) Linking Pattern and Process in Cultural Landscapes. An Empirical Study Based on Spatially Explicit Indicators. Land Use Policy, 21, 289-306. http://dx.doi.org/10.1016/j.landusepol.2003.10.012

[18] IBGE (2014) Resolution No. 2 of 26 August, 2014. Estimates of the Population for the States and Municipalities with Reference Date on 1 July, 2014. Official Federal Gazette, Brazil, 28 August, Section 1, 115.

[19] Soares, J.J., Silva, D.W. and Lima, M.I.S. (2003) Current State and Projection of the Probable Original Vegetation of the São Carlos Region of São Paulo State, Brazil. Brazilian Journal of Biology, 63, 527-536. http://dx.doi.org/10.1590/S1519-69842003000300019

[20] Cintra, R.H.S., Santos, J.E., Moschini, L.E., Pires, J.S.R. and Henke-Oliveira, C. (2006) Qualitative and Quantitative Analysis of Environmental Damages through Instauration and Registers of Lawful Documents. Brazilian Archives of Biology and Technology, 49, 989-999. http://dx.doi.org/10.1590/S1516-89132006000700017

[21] Bertini, M.A., Fushita, A.T. and Lima, M.I.S. (2015) Vegetation Coverage in Hydrographic Basins in the Central Region of the State of São Paulo, Brazil. Brazilian Journal of Biology, 75, 709-717. http://dx.doi.org/10.1590/1519-6984.21713

[22] Crosta, A.P. (1992) Remote Sensing Digital Image Processing. Campinas: IG/UNICAMP.

[23] Moreira, M.A. (2011) Remote Sensing Fundamentals and Application Methods. 4th Edition, UFV, Brazil.

[24] Haber, W. (1994) Systems Ecological Concepts for Environmental Planning. In: Klijn, F., Ed., Ecosystem Classification for Environmental Management, Springer, Netherlands, 49-68. http://dx.doi.org/10.1007/978-94-017-1384-9_3

[25] Nelson, G.C., Bennette, B.A.A., Cassman, K., Defries, R., Dietz, T., Dobermann, A., Dobson, A., Janetos, A., Levy, M., Marco, D., Nakicenovic, N., O’Neill, B., Norgaard, R., Petschel-Held, G., Ojima, D., Pingali, P., Watson, R. and Zurek, M. (2006) Anthropogenic Drivers of Ecosystem Change: An Overview. Ecology and Society, 11, 29-38

[26] O’Neill, R.V., Krummel, J.R., Gardner, R.H., Sugihara, G., Jackson, B., De Angelis, D.L., Milne, B.T., Turner, M.G., Zygmunt, B., Christensen, S.W., Dale, V.H. and Graham, R.L. (1988) Indices of Landscape Pattern. Landscape Ecology, 3, 153-162. http://dx.doi.org/10.1007/BF00162741

[27] Eastman, J.R. (2012) IDRISI Selva. Clark University, Worcester, MA. 
[28] Adger, W.N. (2006) Vulnerability. Global Environmental Change, 16, 268-281. http://dx.doi.org/10.1016/j.gloenvcha.2006.02.006

[29] Canter, L.W. (1996) Environmental Impact Assessment. Series in Water Environmental Resources. Engineering. 2nd Edition, McGraw-Hill International Editions, Amsterdam, 660 p.

[30] Bojórquez-Tapia, L.A., Juárez, L. and Cruz-Bello, G. (2002) Integrating Fuzzy Logic, Optimization and GIS for Ecological Impact Assessments. Environmental Management, 30, 418-433. http://dx.doi.org/10.1007/s00267-002-2655-1

[31] Anderson, M.J. (2001) A New Method for Non-Parametric Multivariate Analysis of Variance. Austral Ecology, 26, 3246. http://dx.doi.org/10.1046/j.1442-9993.2001.01070.x

[32] Anderson, M.J. (2005) Permanova: A Fortran Computer Program for Permutational Multivariate Analysis of Variance. Department of Statistics, University of Auckland, Auckland.

[33] Constanza, R., d’Arge, R., De Groot, R.S., Farberk, S., Grasso, M., Hannon, B., Limburg, K., Naeem, S., O’Neill, R.V., Paruelo, J., Raskin, R.G., Suttonkk, P. and Van Den Belt, M. (1997) The Total Value of the World's Ecosystem Services and Natural Capital. Nature, 387, 253-260. http://dx.doi.org/10.1038/387253a0

[34] De Groot, R.S., Wilson, A. and Boumans, R.M.J. (2002) A Typology for the Classification, Description and Valuation of Ecosystem Functions, Goods and Services. Ecological Economics, 41, 393-408. http://dx.doi.org/10.1016/S0921-8009(02)00089-7

[35] Wiggering, H., Mueller, K., Werner, A. and Helming, K. (2003) The Concept of Multi-Functionality in Sustainable Land Development. In: Helming, K. and Wiggering, H., Eds., Sustainable Development of Multifunctional Landscapes, Springer, Berlin, Heidelberg. http://dx.doi.org/10.1007/978-3-662-05240-2_1

[36] De Groot, R.S. (2006) Function Analysis and Valuation as a Tool to Assess Land Use Conflicts in Planning for Sustainable Multifunctional Landscapes. Landscape and Urban Planning, 75, 175-186. http://dx.doi.org/10.1016/j.landurbplan.2005.02.016

[37] Hijmans, R.J., Phillips, S., Leathwick, J. and Elith, J. (2014) Dismo: Species Distribution Modeling. http://CRAN.R-project.org/package=dismo

[38] Hijmans, R.J., van Etten, J., Cheng, J., et al. (2015) Raster: Geographic Data Analysis and Modeling. http://CRAN.R-project.org/package=raster

[39] R Core Team (2013) R: A Language and Environment for Statistical Computing. R Foundation for Statistical Computing, Vienna, Austria. http://www.R-project.org/ 